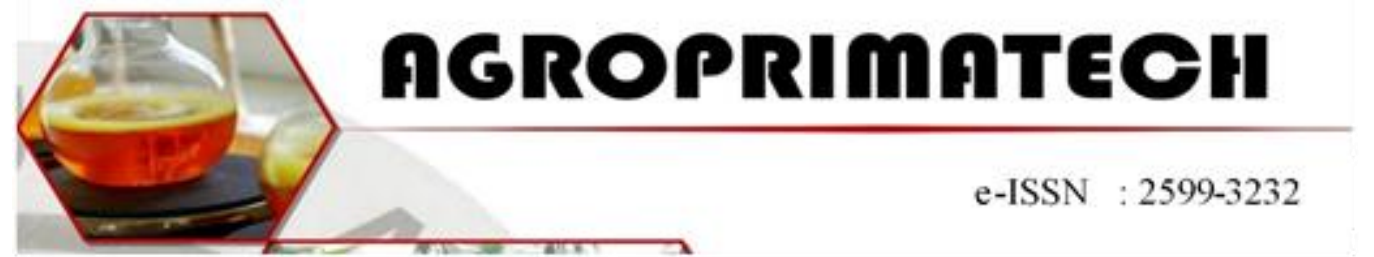

\title{
RESPON PERTUMBUHAN JAGUNG (Zea mays L.) TERHADAP PEMBERIAN KOMPOSISI DAN DOSIS PUPUK ORGANIK
}

\author{
ASEP IKHSAN GUMELAR ${ }^{1}$, YULIANA SEUK BERE ${ }^{2}$, WILDA LUMBAN TOBING ${ }^{3}$ \\ 1,2,3, Program Studi Agroteknologi, Fakultas Pertanian, Universitas Timor \\ email: wildatobing@unimor.ac.id
}

\begin{abstract}
ABSTRAK
Budidaya jagung banyak dilakukan masyarakat Timor Tengah Utara (TTU) sebagai upaya memenuhi kebutuhan pangan. Peningkatan produksi jagung d TTU di lahan kering perlu ditingkatkan. Penelitian ini bertujuan untuk mengetahui pertumbuhan dengan pemberian komposisi dan jenis pupuk organik. Penelitian dilaksanakan pada lahan percobaan Fakultas Pertanian Universitas Timor yang dilaksanakan pada bulan September -Desember 2020. Metode yang digunakan eksperimen dengan Rancangan Akan Kelompok (RAK) non faktorial yang terdiri dari 9 kombinasi perlakuan yaitu: $\mathrm{F} 1=$ pupuk kandang sapi:tanah (1:1) dan POC ml/500 ml, F2 = pupuk kandang sapi:tanah (1:1) dan POC $2 \mathrm{ml} / 500 \mathrm{ml}, \mathrm{F} 3=$ pupuk kandang sapi:tanah (1:1) dan POC $3 \mathrm{ml} / 500 \mathrm{ml}, \mathrm{F} 4$ = pupuk kandang kambing:tanah (1:1) dan POC $1 \mathrm{ml} / 500 \mathrm{ml}, \mathrm{F} 5$ = pupuk kandang kambing:tanah (1:1) dan POC 2 $\mathrm{ml} / 500 \mathrm{ml}, \mathrm{F} 6$ = pupuk kandang kambing:tanah $(1: 1)$ dan POC $3 \mathrm{ml} / 500 \mathrm{ml}, \mathrm{F} 7$ = pupuk kandang sapi:pupuk kandang kambing:tanah (1:1:1) dan POC $1 \mathrm{ml} / 500 \mathrm{ml}$, F8 = pupuk kandang sapi:pupuk kandang kambing:tanah (1:1:1) dan POC $2 \mathrm{ml} / 500 \mathrm{ml}$, F9 = pupuk kandang sapi:pupuk kandang kambing:tanah (1:1:1) dan POC $3 \mathrm{ml} / 500 \mathrm{ml}$. Seluruh perlakuan diulang sebanyak 3 kali sehingga total percobaan adalah 27 unit. Hasil penelitian menunjukkkab bahwa komposisi dan jenis pupuk berpengaruh nyata terhadapat tinggi dan diameter batang tanaman jagung dengan pemberian pupuk kandang kambing:tanah (1:1) dan POC $1 \mathrm{ml} / 500 \mathrm{ml}$.
\end{abstract}

Kata Kunci : Lahan Kering, Pupuk Kandang Kambing, Pupuk Kandang Sapi, Pupuk Organik Cair

\section{PENDAHULUAN}

Masyarakat Indonesia pada umumnya mengkonsumsi bersa sebagai kebutuhan pangan utama. Selain itu, jagung juga merupakan pangan penting yang dapat dikonsumsi masyarakat selain beras. Masyrakat Nusa Tenggara Timur (NTT) termasuk kabupaten Timor Tengah Utara (TTU) banyak melakukan budidaya tanaman jagung. Selain itu, olahan makan dari jagung merupakan bahan makanan untuk oalahan khas dari TTU bahkan NTT. TTU memiliki lahan ataupun tanah yang kering, namun tetap diusahakan masayarakat untuk memenuhi kebutuhan pangannya. Diketahui luasan lahan kering di TTU sebesar 167.637 ha atau sekitar 62,79 persen dari luas wilayah kabupaten
(Badan Pusat Statistik Kabupaten TTU, 2016). Pengembangan lahan kering di Kabupaten Timor Tengah Utara melalui 4 (empat) produk unggulan pertanian yaitu komoditi padi (padi ladang), komoditi jagung, komoditi kacang tanah dan komoditi bawang putih lokal (Malelak, 2018).

Menurut data BPS NTT (2016), pada wilayah Kabupaten Timor Tengah Utara (TTU) luas panen jagung pada tahun 2016 25,114 ha dengan produktifitas 25,36 $\mathrm{kw} / \mathrm{ha}$ dari produksi 63,677 ton, masih jauh lebih rendah dibandingkan diwilayah lain seperti kabupaten Manggarai Timur yang produktivitasnya mencapai $32,33 \mathrm{kw} / \mathrm{ha}$. Hal ini dapat disebabkan kondisi lingkungan dengan lahan yang kering. 
Beberapa permasalahan dalam budidaya jagung di lahan kering yang menyebabkan produktivitas rendah, selain karena faktor abiotis dan biotis, juga disebabkan karena teknik budidaya masih tradisional, menggunakan varietas potensi hasil rendah, populasi tanaman rendah, dan penggunaan pupuk yang belum optimal (Balitsereal, 2006). Kondisi lahan kering memiliki ciri dengan solum yang dangkal dan berbatu (Bria et al., 2021). Sehingga pemanfaatannya untuk budidaya jagung memerlukan masukan seperti pupuk organik seperti penggunaan pupuk kandang dan pupuk organik cair.

Pupuk kandang berasal dari feses ternak seperti sapi, kambing, ayam, dan hewan ternak lainnya. Kemampuan pupuk kandang dalam memperbaiki fisik tanah dapat membantu menyediakan nutrisi nagi tanaman. Ketersediaan bahan organik pada tanah mampu meningkatkan kapasitas tukar kation tanah sehingga membantu ketersediaan hara yang belum larut. Pupuk kandang dapat meningkatkan kualitas biologis tanahsifat serta nutrisi, produksi, dan kualitas tanaman yang diperoleh (Asroh, 2010; Tiamiyu et al., 2013; Eivazi, 2010). Selain pupuk kandang, penggunaan pupuk organik cair digunakan untuk tanaman diharapkan mampu menyediakan hara pada tanaman. Aplikasinya yang langsung mengenai tanaman mampu memberikan nutrisi secara langsung. pupuk organik cair mampu memberi nilai tambah bagi tanaman pada saat pertumbuhan dan perkembangan tanaman, selain itu pupuk ini juga bermanfaat dalam memperbaiki tanah dan mengandung mikroorganisme yang dapat mengurangi serangan penyakit pada tanaman yang dipupuk (Damanik et al., 2011). Hasil penelitian Marpaung et al. (2014), pemanfaatan pupuk organik cair dengan dosis $6 \mathrm{ml} / \mathrm{l}$ air dan teknik penanaman dengan mulsa dapat meningkatkan pertumbuhan vegetatif tanaman kentang sebesar $84,48 \%$ pada umur 1 BST dan $98,68 \%$ setelah berumur 2 BST. Tujuan penelitian ini adalah untuk mengetahui pertumbuhan jagung dengan pemberian komposisi dan jenis pupuk organik.

\section{METODE PENELITIAN}

Penelitian dilaksanakan pada lahan percobaan Fakultas Pertanian Universitas Timor yang dilaksanakan pada bulan September -Desember 2020. Metode yang digunakan eksperimen dengan Rancangan Akan Kelompok (RAK) non faktorial yang terdiri dari 9 kombinasi perlakuan yaitu: $\mathrm{F} 1=$ pupuk kandang sapi:tanah (1:1) dan POC $\mathrm{ml} / 500 \mathrm{ml}$, F2 = pupuk kandang sapi:tanah (1:1) dan POC $2 \mathrm{ml} / 500 \mathrm{ml}, \mathrm{F} 3$ = pupuk kandang sapi:tanah (1:1) dan POC $3 \mathrm{ml} / 500 \mathrm{ml}, \mathrm{F} 4$ = pupuk kandang kambing:tanah (1:1) dan POC $1 \mathrm{ml} / 500 \mathrm{ml}$, F5 = pupuk kandang kambing:tanah (1:1) dan POC $2 \mathrm{ml} / 500 \mathrm{ml}, \mathrm{F} 6$ = pupuk kandang kambing:tanah (1:1) dan POC $3 \mathrm{ml} / 500 \mathrm{ml}$, F7 = pupuk kandang sapi:pupuk kandang kambing:tanah (1:1:1) dan POC $1 \mathrm{ml} / 500$ $\mathrm{ml}, \mathrm{F} 8=$ pupuk kandang sapi:pupuk kandang kambing:tanah (1:1:1) dan POC 2 $\mathrm{ml} / 500 \mathrm{ml}, \mathrm{F9}=$ pupuk kandang sapi:pupuk kandang kambing:tanah (1:1:1) dan POC 3 $\mathrm{ml} / 500 \mathrm{ml}$. Seluruh perlakuan diulang sebanyak 3 kali sehingga total percobaan adalah 27 unit. Hasil pengamatan dianalisis dengan menggunakan sidik ragam (Anova). Jika terdapat pengaruh nyata maka rata-rata perlakuan selanjutnya diuji lanjut dengan menggunakan Duncan Mutliple Range Test (DMRT).

Penelitian dimulai dengan persiapan benih, persiapan media tanah sesuai perlakuan komposisi dan jenis pupuk kandang, penanaman, aplikasi pemupukan cair, pemeliharaan tanaman dan panen yang dilakukan pada umur 49 HST. Parameter yang diamati adalah tinggi tanaman, jumlah daun dan diameter batang.

\section{HASIL DAN PEMBAHASAN}

Berdasarkan hasil pengamatan diketahui bahwa komposisi dan jenis pupuk organik berpengaruh nyata pada pertumbuhan tinggi tanaman dan diameter batang Hasil pengujian diambil pada akhir masa tanaman jagung yaitu 49 HST. Namun komposisi dan jenis pupuk organik berpengaruh tidak nyata pada 
pertumbuhan jumlah daun. Hasil

pengamatan terdapat pada Tabel 1.

Tabel 1. Pertumbuhan tinggi tanaman, jumlah daun, dan diameter batang jagung terhadap pemberian komposisi dan jenis pupuk organik

\begin{tabular}{|c|c|c|c|}
\hline Perlakuan komposisi dan jenis pupuk organik & $\begin{array}{l}\text { Tinggi } \\
\text { tanaman }(\mathrm{cm})\end{array}$ & $\begin{array}{l}\text { Jumlah daun } \\
\text { (helai) }\end{array}$ & $\begin{array}{l}\text { Diameter } \\
\text { batang }(\mathrm{cm})\end{array}$ \\
\hline $\begin{array}{l}\text { F1 (pupuk kandang sapi:tanah (1:1) dan POC ml/500 } \\
\text { ml) }\end{array}$ & $155,00 \mathrm{abcd}$ & 13,50 & $2,50 \mathrm{c}$ \\
\hline $\begin{array}{l}\text { F2 (pupuk kandang sapi:tanah (1:1) dan POC } 2 \\
\mathrm{ml} / 500 \mathrm{ml} \text { ) }\end{array}$ & $131,67 \mathrm{de}$ & 12,33 & $2,50 \mathrm{c}$ \\
\hline $\begin{array}{l}\text { F3 (pupuk kandang sapi:tanah (1:1) dan POC } 3 \text { ml/500 } \\
\text { ml) }\end{array}$ & $153,33 a b c d$ & 13,67 & $2,50 \mathrm{c}$ \\
\hline $\begin{array}{l}\text { F4 (pupuk kandang kambing:tanah (1:1) dan POC } 1 \\
\mathrm{ml} / 500 \mathrm{ml} \text { ) }\end{array}$ & $156,67 a b c$ & 14,00 & $2,80 a$ \\
\hline $\begin{array}{l}\text { F5 (pupuk kandang kambing:tanah (1:1) dan POC } 2 \\
\mathrm{ml} / 500 \mathrm{ml} \text { ) }\end{array}$ & $140,00 \mathrm{bcde}$ & 13,67 & $2,70 a b c$ \\
\hline $\begin{array}{l}\text { F6 (pupuk kandang kambing:tanah (1:1) dan POC } 3 \\
\mathrm{ml} / 500 \mathrm{ml} \text { ) }\end{array}$ & $160,00 a b$ & 13,00 & $2,60 a b c$ \\
\hline $\begin{array}{l}\text { F7 (pupuk kandang sapi:pupuk kandang } \\
\text { kambing:tanah (1:1:1) dan POC } 1 \mathrm{ml} / 500 \mathrm{ml} \text { ) }\end{array}$ & $133,33 \mathrm{cde}$ & 14,00 & $2,80 a$ \\
\hline $\begin{array}{l}\text { F8 (pupuk kandang sapi:pupuk kandang } \\
\text { kambing:tanah (1:1:1) dan POC } 2 \mathrm{ml} / 500 \mathrm{ml})\end{array}$ & $123,33 e$ & 13,00 & $2,60 a b c$ \\
\hline $\begin{array}{l}\text { F9 (pupuk kandang sapi:pupuk kandang } \\
\text { kambing:tanah }(1: 1: 1 \text { ) dan POC } 3 \mathrm{ml} / 500 \mathrm{ml} \text { ) }\end{array}$ & $168,33 a$ & 13,67 & $2,80 \mathrm{a}$ \\
\hline
\end{tabular}

Keterangan : Angka pada kolom diikuti huruf yang tidak sama menunjukkan beda pada tingkat nyata $(\alpha) 5 \%$ menurut uji DMRT.

Pengamatan tinggi tanaman dengan perlakuan pemberian pupuk kandang sapi:pupuk kandang kambing:tanah (1:1:1) dan POC $3 \mathrm{ml} / 500 \mathrm{ml}$ (F9) menunjukkan hasil yang tidak berbeda nyata dibanding perlakuan pemberian pupuk kandang sapi:tanah (1:1) dan POC ml/500 ml (F1), pupuk kandang sapi:tanah (1:1) dan POC $3 \mathrm{ml} / 500 \mathrm{ml}$ (F3), pupuk kandang kambing:tanah (1:1) dan POC $1 \mathrm{ml} / 500 \mathrm{ml}$ (F4), dan pupuk kandang kambing:tanah (1:1) dan POC $3 \mathrm{ml} / 500 \mathrm{ml}$ (F6). Namun perlakuan yang menujukkan tinggi tanaman yang terbaik dihasilkan oleh perlakuan F9. Hal ini diduga karena adanya pemberian pupuk kandang sapi dan pupuk kandang sampi serta pemberian pupuk organik cair $3 \mathrm{ml} / 500 \mathrm{ml}$ mampu menyediakan nutrisi bagi tanaman. Media tanam yang baik dapat dipengaruhi oleh komposisi di dalam tanah. Pemberian bahan organik seperti pupuk kandang mampu memperbaiki kesuburan tanah sehingga mampu menunjang pertumbuhan tanaman dengan baik. Pengamatan diameter batang menunjukkan bahwa pupuk kandang kambing:tanah (1:1) dan POC $1 \mathrm{ml} / 500 \mathrm{ml}$ (F4), pupuk kandang sapi:pupuk kandang kambing:tanah (1:1:1) dan POC $1 \mathrm{ml} / 500 \mathrm{ml}(\mathrm{F} 7)$, dan pemberian pupuk kandang sapi:pupuk kandang kambing:tanah (1:1:1) dan POC $3 \mathrm{ml} / 500$ $\mathrm{ml}$ (F9) menunjukkan hasil yang terbaik. Namun perlakuan tersebut berbeda tidka nyata dengan perlakuan pupuk kandang kambing:tanah (1:1) dan POC $2 \mathrm{ml} / 500 \mathrm{ml}$ (F5), pupuk kandang kambing:tanah (1:1) dan POC $3 \mathrm{ml} / 500 \mathrm{ml}$ (F6), dan pupuk kandang sapi:pupuk kandang kambing:tanah (1:1:1) dan POC $2 \mathrm{ml} / 500$ $\mathrm{ml}$ (F8). Pengamatan jumlah daun tidak menunjukkan pengaruh nyata. Namun, pemberian pupuk kandang kambing:tanah (1:1) dan POC $1 \mathrm{ml} / 500 \mathrm{ml}$ (F4) menunjukkan jumlah daun terbanyak dibanding denagn perlakuan lainnya.

Secara keseluruhan, pemberian pupuk kandang kambing:tanah (1:1) dan POC 1 $\mathrm{ml} / 500 \mathrm{ml}$ (F4) sudah cukup untuk meningkatkan pertumbuhan tanaman. Pada tinggi tanaman diketahui F9 menunjukkan angka tertinggi namun berbeda tidak nyata dengan F4. Oleh karena itu, pemberian pupuk kandang kambing:tanah (1:1) dan POC $1 \mathrm{ml} / 500 \mathrm{ml}$ (F4) diduga sudah cukup memenuhi nutrisi bagi tanaman jagung. Hariadi et al., 2016 menyatakan bahwa aplikasi kotoran sapi dan kotoran kambing meningkatkan pertumbuhan jagung dengan pertumbuhan 
optimal jagung pada media tanah yang mengandung 1/3 kotoran kambing dan 2/3 tanah. Kemudian diikuti dengan pemberian komposisi 1/3 kotoran sapi dan 2/3 tanah. Hasil penelitian Putra et al. (2015) menunjukkan pemberian pupuk kandang mampu meningkatkan pertumbuhan jagung pada tanah Inceptisol. Lukiwati dan Slamet (2021) menunjukkan bahwa pertumbuhan jagung manis meningkatkan dengan adanya pemberian pupuk kandang kambing pada media dibandingkan dengan pemberian pupuk kandang_pupuk anorganik. Selain pemberian pupuk kandang kambing, pemberian pupuk kandang sapi juga memberi pengaruh pada pertumbuhan jagung. Waniyo et al., (2013) menyatakan bahwa ada respon positif pada pertumbuhan dna produksi tanaman jagung dengan adanya pemberian pupuk kandang sapi 10 t/ha. Namun pada penelitian jika dibanding penggunaan pupuk kandang sapi dan pupuk kandnag kambing ataupun kombinasi keduanya dengan tanah menunjukkan pupuk kambing lebih mempunyai pengaruh banyak dalam meingkatkan pertumbuhan tanaman jagung dibandingkan pupuk kandang sapi. Hal ini diduga karena sifat pupuk kandang sapi yang bersifat dingin sehingga lambat dalam proses perombakan dan lambat menyediakan nutrisi bagi tanaman (Arifah, 2013). Pada intinya, penggunaan pupuk kandang baik untuk pertumbuhan jagung. Aplikais pupuk kandang dengan takaran $7 \mathrm{t} /$ ha adalah pemupukan yang paling tepat untuk pertumbuhan jagung di lahan kering (Hou et al., 2012).

Jika dilihat dari kombinasi pupuk kandang dnegan POC maka hasil pengamatan menunjukkan bahwa pemberian POC 1 $\mathrm{ml} / 500 \mathrm{ml}$ air sudha cukup meningkatkan pertumbuhan jagung. Kandungan hara seperti N, $P$, dan $K$ pada POC dikombinasikan dengan pupuk kandang sudah menjadi konsentrasi yang paling baik. Jika diberikan lebih secara umum menunjukkan hasil yang lebih rendah atau tidak ada beda nyata dengan pemberian POC lebih banyak. Maulintar (2019) menyatakan bahwa interaksi pemberian pupuk kandang kambing dengan POC memberikan pengaruh yang nyata terhadap pertumbuhan tinggi tanaman jagung.

\section{KESIMPULAN}

Berdasarakan penelitian dapat diketahui bahwa komposisi dan jenis pupuk berpengaruh nyata terhadapat tinggi dan diammeter batang tanaman jagung dengan pemberian kandang kambing:tanah (1:1) dan POC $1 \mathrm{ml} / 500 \mathrm{ml}$.

\section{Daftar Pustaka}

Asroh, A., 2010. Pengaruh Takaran Pupuk Kandang dan Interval Pemberian Pupuk Hayati terhadap Pertumbuhan dan Hasil Tanaman Jagung Manis (Zea mays Saccharata Linn). Agrobis 2(4), 1-6.

Arifah, S. M. (2013). Aplikasi macam dan dosis pupuk kandang pada tanaman kentang. Jurnal Gamma, 8(2).

Balitsereal. 2006. Deliniasi Percepatan Pengembangan Teknologi PTT Jagung pada Beberapa Agroekosistem. Bahan Padu Padan Puslitbangtan dengan BPTP. Bogor, 13-14 Maret 2006. balitsereal Maros, 14 hal.

BPS Kabupaten TTU. 2016. Timor Utara Dalam Angka 2016 Kerjasama Bappeda TTU dan Badan Pusat Statistik Kabupaten TTU. Badan Pusat Statistik Kabupaten Timor Tengah Utara, Kefamenanu.

Bria, L.N, Sipayung, B. P., Tobing, W. L. 2021. Pemanfaatan Lahan Pekarangan Melalui Sistem Vertikultur Budidaya Sayuran Kelompok Tani Sinar Manumuti Desa Upfaon. Bakti Cendana, 4(1), 68-75.

Damanik, M.M.B., Bacthiar E.H., Fauzi, Sarifuddin, dan Hamidah H. 2011. Kesuburan Tanah danPemupukan USU Press, Medan. Hal 262.

Eivazi, A.R.,Rastegarni, A.R., Habibzadeh, Y., Mogaddam, A.F., Khililzadeh, G., 2013. Influence of Manure Fertilizers on Morphophysiological Traits of Tomato (Lycopersicun escutentum 
Mill). Peak Journal of Agricultural Sciences 16, 89-93.

Hariadi, Y. C., Nurhayati, A. Y., \& Hariyani, P. 2016. Biophysical monitoring on the effect on different composition of goat and cow manure on the growth response of maize to support sustainability. Agriculture and Agricultural Science Procedia, 9, 118-127.

Hou, X., Wang, X., Li, R., Jia, Z., Liang, L., Wang, J., \& Wang, Z. 2012. Effects of different manure application rates on soil properties, nutrient use, and crop yield during dryland maize farming. Soil Research, 50(6), 507514.

Lukiwati, D. R., \& Slamet, W. (2021, July). Improvement of plant growth and production of sweet corn with organic- $\mathrm{N}$ and nature- $\mathrm{P}$ enriched manure and inorganic fertilizer in Batang District of Central Java Indonesia. In IOP Conference Series: Earth and Environmental Science (Vol. 803, No. 1, p. 012016). IOP Publishing.

Putra, A. D., Damanik, M. M. B., \& Hanum, H. 2015. Aplikasi pupuk area dan pupuk kandang kambing untuk meningkatkan $\mathrm{N}$ total tanah pada inceptisol Kwala Bekala dan kaitannya trhadap pertumbuhan jagung (Zea mays L.). Jurnal Agroekoteknologi Universitas Sumatera Utara, 3(1), 102726.

Malelak, C. 2018. Potensi Pengembangan Produk Unggulan Pertanian Lahan Kering Kabupaten Timor Tengah Utara. EVOLUSI: JOURNAL OF MATHEMATICS AND SCIENCES, 2 (1), 85-97.

Marpaung, A. E., Karo, B., \& Tarigan, R. (2014). Pemanfaatan pupuk organik cair dan teknik penanaman dalam peningkatan pertumbuhan dan hasil kentang. Jurnal Hortikultura, 24(1), 49-55.

Maulintar, B. (2019). Pengaruh Aplikasi Pupuk Organik Cair Sabut Kelapa dan Pupuk Kandang Kambing terhadap Pertumbuhan dan Produksi Tanaman Jagung Manis (Zea mays
Sacharata). Kumpulan Karya IImiah Mahasiswa Fakultas sains dan Tekhnologi, 1(1), 59-59.

Putra, A. D., Damanik, M. M. B., \& Hanum, H. (2015). Aplikasi pupuk area dan pupuk kandang kambing untuk meningkatkan $\mathrm{N}$ total tanah pada inceptisol Kwala Bekala dan kaitannya trhadap pertumbuhan jagung (Zea mays L.). Jurnal Agroekoteknologi Universitas Sumatera Utara, 3(1), 102726.

Tiamiyu, R.A., Ahmed, H.G., Muhammad, A.S., 2012. Effect of Source of Organic Manure on Growth and Yields of Okra (Abelmoschus esculentus L.) in Sokoto, Nigeria. Nigerian Journal of Basic and Applied Science 20(3), 2013-2016.

Waniyo, U. U., Sauwa, M. M., Ngala, A. L., Abubakar, G. A., \& Anelo, E. C. 2013. Influence of sources and rates of manure on yield and nutrient uptake of maize (Zea mays L.) in Maiduguri, Nigeria. Nigerian Journal of Basic and Applied Sciences, 21(4), 259265. 